\title{
ISOLASI DAN SELEKSI BAKTERI SALURAN PENCERNAAN IKAN LELE SEBAGAI UPAYA MENDAPATKAN KANDIDAT PROBIOTIK UNTUK EFISIENSI PAKAN IKAN
}

\author{
Titin Kurniasih*), Angela Mariana Lusiastuti*), Zafril Imran Azwar**, dan \\ Irma Melati*) \\ *) Balai Penelitian dan Pengembangan Budidaya Air Tawar \\ Jl. Sempur No. 1, Bogor 16154 \\ E-mail: titink2008@yahoo.com
}

Pusat Penelitian dan Pengembangan Perikanan Budidaya

Jl. Ragunan No. 20, Pasar Minggu, Jakarta Selatan 12540

(Naskah diterima: 28 Mei 2013; Disetujui publikasi: 30 Desember 2013)

\begin{abstract}
ABSTRAK
Bakteri yang diisolasi dari saluran pencernaan yang mempunyai aktivitas amilolitik (mencerna karbohidrat), proteolitik (mencerna protein), dan lipolitik (mencerna lemak) dapat dimanfaatkan untuk meningkatkan daya cerna bahan pakan. Penelitian ini bertujuan mendapatkan bakteri dari saluran pencernaan ikan lele yang memiliki aktivitas amilolitik, proteolitik, dan lipolitik serta berpotensi menjadi probiotik pakan. Tahapan penelitian meliputi kultur dan isolasi bakteri pada media universal dengan penambahan pati, kasein, dan minyak zaitun masing- masing sebanyak $2 \%$ dilanjutkan dengan uji hidrolisis karbohidrat (pati), protein (kasein), dan lemak (minyak zaitun). Hasilnya didapatkan dua isolat dari kelompok bakteri proteolitik, dua isolat dari kelompok amilolitik dan tiga isolat dari kelompok lipolitik. Kandidat bakteri probiotik tersebut berasal dari genus Staphylococcus, Micrococcus, Corynebacterium, Bacillus, Lactobacillus, Aerococcus, dan Streptococcus.
\end{abstract}

KATA KUNCI: bakteri, saluran pencernaan, hidrolisis, kandidat probiotik

ABSTRACT: Isolation and selection of the African catfish intestinal bacterias to obtain probiotic candidate for fish feed efficiency. By: Titin Kurniasih, Angela Mariana Lusiastuti, Zafril Imran Azwar, and Irma Melati

Bacterias that were isolated from gastro-intestinal tractus have potential activity as amilolitic (carbohydrate digestion), proteolitic (protein digestion), and lipolitic (lipid digestion) which are able to enhance digestive activity. The aim of this research was to obtain the amylolytic, proteolytic, and lipolytic bacterias from catfish intestine which could be potentially used as feed probiotic. This work included the bacterial culture, isolation, and selection using universal medium which were supplemented with $2 \%$ of starch, casein, and zaitun oil (olive oil). This work has succesfully obtained two isolates of proteolitic bacteria, two isolates from amilolitic bacteria and three isolates from lipolitic bacteria. The choosen candidates for future use as digestive bacteria were from genus Staphylococcus, Micrococcus, Corynebacterium, Bacillus, Lactobacillus, Aerococcus, dan Streptococcus.

KEYWORDS: bacterias, gastrointestinal tract, hydrolysis, probiotic candidates 


\section{PENDAHULUAN}

Sistem pencernaan pada ikan lebih sederhana dibandingkan hewan darat, sehingga mekanisme pencernaan atau daya cerna terhadap pakan sangat terbatas. Mengingat keterbatasan terhadap kesediaan enzim pencernaan, ikan memanfaatkan energi sumber karbohidrat dalam jumlah sedikit karena rendahnya sekresi enzim amilase untuk pencernaan dan insulin untuk metabolisme. Demikian juga enzim lipase yang mampu menguraikan lemak menjadi sumber energi sangat terbatas pada ikan. Kadar nutrien pakan formulasi yang cukup tinggi tidak diimbangi oleh kemampuan ikan untuk mencerna dan mengabsorbsi nutrien (protein, lemak, dan karbohidrat) yang tersedia. Sehingga pakan yang diberikan akan diekskresikan dalam kondisi nutrien masih tinggi. Di samping itu, sebagian bahan baku pakan berasal dari sumber nabati, dan memiliki ikatan kompleks yang mengakibatkan senyawa protein dan fosfat sulit mengalami proses degradasi, akibatnya kandungan fosfat yang tinggi terbuang percuma ke medium kultur (Aslamyah, 2006).

Salah satu alternatif pemecahan masalah tersebut adalah dengan meningkatkan ketersediaan enzim pencernaan eksogen dengan memanfaatkan bakteri berasal dari saluran pencernaan yang mempunyai aktivitas amilolitik (mencerna karbohidrat), proteolitik (mencerna protein), dan lipolitik (mencerna lemak). Bakteri yang disebut sebagai probiotik akan mengatur lingkungan mikroba dalam usus, menghalangi mikroorganisme patogen usus dan memperbaiki efisiensi pakan dengan melepas enzim- enzim yang membantu proses pencernaan.

Penelitian Aslamyah (2006), telah membuktikan bahwa bakteri amilolitik yang diisolasi dari ikan bandeng mampu meningkatkan ketersediaan karbohidrat pakan sehingga menekan penggunaan sumber energi dari protein. Dari hasil penelitian tersebut didapatkan bakteri yang bersifat: (i) amilolitik (Citrobacter sp., Aeromonas hydrophila, Staphylococcus sp., Flavobacterium sp., Carnobacterium sp., Moraxella sp., dan Vibrio sp.); (ii) proteolitik (Vibrio alginoliticus, Streptococcus sp., Micrococcus sp., Proteus sp., Pseudomonas sp., dan Bacillus sp.); dan (iii) lipolitik (Planococcus sp., Kurthia sp., Serratia sp., dan Plesiomonas sp.) Bakteri- bakteri tersebut selanjutnya dilakukan uji seleksi mikroba untuk memilih mikroba yang memiliki potensi sebagai kandidat probiotik untuk peningkatan pemanfaatan pakan khususnya dalam meningkatkan kecernaan nutrien pakan.

Kriteria probiotik yang sesuai dalam budidaya ikan atau akuakultur adalah bakteri yang dapat memberikan pengaruh positif terhadap ekosistem dan rantai makanan. Menurut Moriarty (1999), probiotik dapat bekerja dengan beberapa cara, yaitu berkompetisi dengan mikroorganisme lain untuk mendapatkan tempat melekat pada tubuh inang; memproduksi senyawa antimikroba sebagai inhibitor seperti antibiotik, bakteriosin, siderophore, lisozim, protease, hidrogen peroksida, dan asam organik yang dapat merubah $\mathrm{pH}$; berkompetisi dengan senyawa kimia atau energi, seperti besi maupun nutrien yang diambil dari inang; meningkatkan respons imun pada inang sehingga tahan terhadap serangan virus, bakteri, jamur maupun parasit, memperbaiki kualitas air, berinteraksi dengan fitoplankton; sebagai sumber nutrisi makro dan mikro, dan memberikan kontribusi enzim pencernaan.

Penelitian ini bertujuan untuk memperoleh bakteri yang memiliki aktivitas amilolitik, proteolitik, dan lipolitik dari sistem pencernaan ikan lele, sebagai kandidat probiotik pakan untuk memperbaiki efisiensi kecernaan pakan dan meningkatkan fungsi fisiologis ikan terutama kemampuannya dalam mencerna pakan.

\section{BAHAN DAN METODE}

Tahapan untuk mendapat kandidat probiotik dilakukan kegiatan meliputi:

\section{Isolasi Mikroba}

Pengambilan isi saluran pencernaan ikan lele sebagai sumber inokulum dengan cara mengeluarkan organ pencernaan (lambung dan usus) dari ikan lele fase dewasa yang telah dimatikan sebelumnya dengan cara menusuk dan menghancurkan bagian otaknya dengan benda tajam. Rata- rata panjang dan bobot dari usus ikan lele adalah $19 \mathrm{~cm}$ dan $5,03 \mathrm{~g}$. Usus tersebut dihaluskan dengan menggunakan mortar kemudian ditambahkan $\mathrm{NaCl}$ 0,85\% sebanyak $495 \mathrm{~mL}$ dan dihomogenkan menggunakan vortex, cairan ini disebut inokulum. Inokulum sebanyak satu $\mathrm{mL}$ dimasukkan dalam tabung reaksi yang berisi Trypticase Soy Broth (TSB) dan masing- masing TSB disuplementasi dengan 2\%skim milk, 2\% 
starch, dan $2 \%$ minyak zaitun. Kemudian diinkubasi selama 24 jam pada suhu $28^{\circ} \mathrm{C}$. Pada masing- masing tabung diambil satu ose untuk disebar ke cawan petri yang berisi TSA dengan kandungan suplemen yang sama seperti dalam TSB tersebut dan diinkubasi selama 24 jam pada suhu $28^{\circ} \mathrm{C}$.

Prosedur isolasi mikroba yang mempunyai aktivitas amilolitik, proteolitik, dan lipolitik dilakukan dengan metode seleksi, yang mengacu pada metode yang dilakukan pada hewan terrestrial (Hungate, 1966) dan dikombinasikan dengan prosedur isolasi mikroba dari saluran pencernaan ikan (Nakayama et al., 1994; Hoshino et al., 1997; Cai et al., 1998; Jankauskiene, 2000).

Kultur mikroba dilakukan dalam suasana aerob dan anaerob. Untuk menciptakan kondisi anaerob setiap proses kegiatan dialiri gas $\mathrm{CO}_{2}$ dan tabung disumbat dengan tutup karet. Media kultur yang digunakan adalah TSB yang ditambah $1 \% \mathrm{NaCl}$. Sebagai sumber energi untuk amilolitik adalah $2 \%$ pati, untuk proteolitik adalah $2 \%$ kasein, dan untuk lipolitik adalah $2 \%$ minyak ikan. Sumber inokulum diambil sebanyak $0,5 \mathrm{~mL}$ dan diinokulasikan ke dalam $10 \mathrm{~mL}$ media cair standar, yaitu TSB ditambah sumber energi (pati, kasein, dan minyak ikan). Kultur dibuat secara duplo. Kultur ini kemudian diinkubasi pada suhu $29^{\circ} \mathrm{C}$ selama 24 jam agar mikroba dapat tumbuh. Pertumbuhan mikroba ditandai oleh keruhnya media kultur.

Untuk mendapatkan isolat murni, dari setiap seri pengenceran ditransfer sebanyak 0,1 $\mathrm{mL}$ ke dalam media padat, yang terdiri atas campuran TSB, TSA, dan sumber energinya dengan menggunakan cawan petri untuk suasana aerob, dan media double layer untuk suasana anaerob. Sediaan ini diinkubasi kembali pada suhu $29^{\circ} \mathrm{C}$ selama 24 sampai 48 jam. Koloni mikroba yang tumbuh dipilih berdasarkan perbedaan morfologi (bentuk, ukuran, dan warna koloni). Metode purifikasi dilakukan berulang- ulang dengan teknik dan media yang sama sampai didapatkan koloni mikroba tunggal dan seragam.

Kultur murni selanjutnya diperbanyak, sebagian isolat mikroba digunakan sebagai kultur stok dan sebagian lagi sebagai inokulum pada percobaan berikutnya. Perbanyakan dilakukan dengan cara menumbuhkan masingmasing isolat ke dalam media yang sesuai dengan media hidupnya, kemudian diinkubasi pada suhu $29^{\circ} \mathrm{C}$ selama 24 jam. Kultur yang didapat siap untuk diawetkan. Pengawetan dilakukan dengan menyimpan isolat murni yang telah diperoleh ke dalam media gliserol yang terdiri atas media broth dan gliserol dengan perbandingan 1:1 yang selanjutnya disebut stok kultur (Badjoeri, 2010).

\section{Seleksi Mikroba (Pengujian Aktivitas} Amilolitik, Proteolitik, dan Lipolitik)

Pengujian ini bertujuan untuk mengukur besarnya aktivitas isolat amilolitik, proteolitik, dan lipolitik masing-masing isolat. Tahapan pengujian adalah uji hidrolisis kasein, pati, dan lemak.

\section{Uji Hidrolisis Kasein}

Media kultur agar yang mengandung kasein dituangkan ke dalam cawan petri. Isolat yang akan diuji diinokulasi ke dalam media agar dengan cara menginokulasikan sebanyak satu mata ose biakan di bagian tengah cawan, kemudian disebarkan seluas $0,5 \mathrm{~cm}$. Selanjutnya diinkubasi pada suhu $29^{\circ} \mathrm{C}$ selama 24 sampai $48 \mathrm{jam}$. Hidrolisis kasein diuji dengan memberikan beberapa tetes larutan $\mathrm{HCl} 10 \%$ di atas permukaan media agar. Jika terjadi proses hidrolisis kasein, akan terlihat daerah bening di sekeliling koloni mikroba, sebaliknya bila tidak terjadi hidrolisis maka daerah di sekitar koloni tetap berwarna keruh. Kemudian diameter wilayah yang hidrolisis diukur.

\section{Uji Hidrolisis Pati}

Media kultur agar yang mengandung pati dituangkan ke dalam cawan petri. Isolat yang akan diuji diinokulasi ke atas media agar dengan cara menginokulasikan sebanyak satu mata ose biakan di bagian tengah cawan kemudian disebarkan seluas $0,5 \mathrm{~cm}$. Selanjutnya diinkubasi pada suhu $29^{\circ} \mathrm{C}$ selama 24 sampai 48 jam. Hidrolisis pati diuji dengan memberikan beberapa tetes larutan lugol iodine di atas permukaan media agar. Jika terjadi proses hidrolisis pati terlihat daerah bening di sekeliling koloni mikrob, sebaliknya bila tidak terjadi hidrolisis daerah sekitar koloni mikroba berwarna biru kehitaman. Diameter wilayah yang mengalami hidrolisis kemudian diukur.

\section{Uji Hidrolisis Lemak}

Media yang digunakan adalah spirit blue agar yang mengandung 3\% reagens bacto lipase (Difco) atau reagen dapat diganti dengan emulsi $100 \mathrm{~mL}$ minyak zaitun dalam $400 \mathrm{~mL}$ air 
panas ditambah $1 \mathrm{~mL}$ Tween $80.30 \mathrm{~mL}$ emulsi ini ditambahkan ke dalam $1.000 \mathrm{~mL}$ spirit blue agar sewaktu agar masih hangat $\left(55^{\circ} \mathrm{C}\right)$. Inokulasi isolat yang akan diuji ke dalam media agar dengan cara menginokulasikan satu ose biakan di bagian tengah cawan, kemudian disebarkan seluas $0,5 \mathrm{~cm}$. Selanjutnya diinkubasi pada suhu $29^{\circ} \mathrm{C}$ selama 24 sampai 48 jam. Hidrolisis lemak ditandai dengan warna biru di sekeliling pertumbuhan koloni mikroba. Bila mikroba tidak menghasilkan lipase, maka wilayah di sekeliling koloni sama dengan warna asal media (biru pucat). Diameter wilayah yang hidrolisis diukur.

\section{Uji Daya Hambat terhadap Patogen Aeromonas hydrophila}

Uji tantang secara in vitro terhadap patogen Aeromonas hydrophila pada kepadatan $10^{8} \mathrm{CFU} / \mathrm{mL}$ dengan kandidat probiotik yang berbeda- beda kepadatannya. Aeromonas hydrophila ditanam terlebih dahulu pada cawan petri dengan metode tuang dan diratakan dengan L-glass. Uji potensi menggunakan kertas cakram yang sudah dicelup dengan probiotik yang berbeda tingkat kepadatannya. Kemudian dilakukan inkubasi pada suhu $28^{\circ} \mathrm{C}$ selama 24 jam. Terbentuknya zona bening di sekitar kertas cakram disebut sebagai zona hambat, memperlihatkan bahwa probiotik dapat menghambat pertumbuhan patogen Aeromonas hydrophila.

\section{Pengawetan dan Penyimpanan Isolat} Kandidat Probiotik

Pengawetan dan penyimpanan isolat kandidat probiotik dilakukan dengan menggu- nakan kombinasi antara gliserol murni dengan media broth (TSB) dengan perbandingan 1: 1 . Kandidat probiotik yang disimpan konsentrasinya $10^{14} \mathrm{CFU} / \mathrm{mL}$. Microtube ditutup rapat, dihomogenkan dan disimpan di freezer suhu $0^{\circ} \mathrm{C}$. Uji recovery dilakukan dengan cara menanam langsung pada media cair atau agar. Uji viabilitas dilakukan satu bulan sekali.

\section{HASIL DAN BAHASAN}

Isolasi dan Identifikasi Kandidat Probiotik dari Saluran Pencernaan Ikan Lele

Tabel 1 menyajikan bobot ikan, bobot usus, dan panjang usus ikan lele, sedangkan hasil isolasi, dan identifikasi kandidat probiotik disajikan pada Tabel 2 sampai Tabel 5.

Tabel 1 menunjukkan kisaran bobot ikan lele uji termasuk ikan lele dewasa adalah $196,25 \mathrm{~g}$ dengan bobot usus rata- rata 3,78 g dan panjang usus rata- rata adalah $19 \mathrm{~cm}$, di mana usus lele ini termasuk berukuran pendek karena lele adalah karnivora. Tabel 1 merupakan data dasar yang diperlukan nantinya berhubungan dengan jenis bakteri yang diperoleh dari isolasi pada usus lele dewasa.

Semua kandidat probiotik hasil isolasi diuji kemampuannya sebagai bakteri proteolitik, amilolitik, dan lipolitik pada kondisi aerob maupun anaerob, mengingat kondisi pertumbuhan bakteri secara normal ada di dalam usus yang minim terhadap kandungan oksigen. Enzim protease merupakan enzim yang menghidrolisis protein menjadi asam-asam amino dan peptida sederhana, enzim lipase mampu merubah lemak menjadi asam- asam

Tabel 1. Bobot ikan, bobot usus, dan panjang usus ikan lele secara pooling dalam empat kali pengambilan sampel

Table 1. Fish weight, intestine weight, and intestine length of catfish are pooling in four times of sample collection

\begin{tabular}{cccc}
\hline $\begin{array}{c}\text { Nomor sampel } \\
\text { Number of samples }\end{array}$ & $\begin{array}{c}\text { Bobot ikan } \\
\text { Fish weight } \\
(\mathbf{g})\end{array}$ & $\begin{array}{c}\text { Bobot usus } \\
\text { Intestine weight } \\
\mathbf{( g )}\end{array}$ & $\begin{array}{c}\text { Panjang usus } \\
\text { Intestine length } \\
\text { (cm) }\end{array}$ \\
\hline 1 & 200 & 5.09 & 17.00 \\
2 & 185 & 2.84 & 21.50 \\
3 & 190 & 2.43 & 21.00 \\
4 & 210 & 4.75 & 16.50 \\
\hline Rataan (Mean) & $\mathbf{1 9 6 . 2 5}$ & $\mathbf{3 . 7 8}$ & $\mathbf{1 9 . 0 0}$ \\
\hline
\end{tabular}


lemak sedangkan enzim amilase merupakan enzim yang mampu menghidrolisis karbohdrat menjadi gula sederhana. Adanya aktivitas enzim- enzim tersebut dalam saluran pencernaan menyebabkan penyerapan nutrisi atau gizi terhadap protein, lemak, dan karbohidrat menjadi lebih baik, sehingga energi yang dihasilkan mampu untuk memenuhi kebutuhan ikan untuk tumbuh, beraktivitas, dan menjadikan sistem imun berjalan maksimal untuk mempertahankan sintasannya.

Untuk bakteri proteolitik yang ditumbuhkan secara aerob pada media TSA suplementasi skim milk $2 \%$ diperoleh dua buah koloni (LL dan PP) seperti yang disajikan pada Tabel 2, sedangkan pada media ananerob dengan teknik double layer diperoleh dua buah koloni (BL dan OL). Tetapi setelah dilakukan pemurnian dan pengujian aktivitas secara berulang-ulang, hanya dua buah koloni saja dengan kode BL dan OL yang konsisten melisis protein dalam hal ini kasein susu.

Antara bakteri aerob dan anaerob pada Tabel 2, terdapat perbedaan dari bentuk koloninya yaitu bentuk bulat untuk isolat PP dan $\mathrm{BL}$, sedangkan LL dan OL berbentuk oval. Permukaan koloni dari keempatnya cenderung cembung dan hanya koloni isolat LL berwarna kuning sedangkan isolat lainnya yaitu $\mathrm{PP}, \mathrm{BL}$, dan OL berwarna putih. Isolat terpilih sebagai kandidat bakteri probiotik yang bersifat proteolitik adalah BL dan OL karena stabil di dalam melisis protein. Perbandingan daya lisis protein antara isolat BL dan OL belum diketahui dengan jelas karena pada waktu pengujian kedua isolat digoreskan pada media agar (streak) dan tidak diuji berdasarkan satu lawan satu koloni.

Tabel 3 memperlihatkan isolat bakteri yang tumbuh pada media TSA dengan suplementasi pati $2 \%$ baik yang ditumbuhkan secara aerob dan anaerob. Penambahan pati pada media TSA berfungsi juga sebagai skrining kemampuan isolat bakteri sehingga bakteri yang tumbuh adalah kelompok yang relatif hanya dapat memanfaatkan pati sebagai substrat. Total kandidat bakteri probiotik yang diperoleh baik aerob maupun anaerob adalah 12 isolat.

Setelah dilakukan uji hidrolisis pati dengan meneteskan larutan lugol iodine pada tiga isolat aerob didapatkan dua jenis bakteri positif amilolitik yaitu isolat A dan isolat 5 , keduanya aerob yang dapat menghidrolisis pati, dibuktikan dengan adanya zona bening pada uji hidrolisis pati (Tabel 3). Sedangkan dari isolat anaerob yaitu isolat nomor 4 sampai 12 ternyata tidak bersifat amilolitik. Isolat A dan isolat 5 , berbeda dalam bentuk dan warna koloni. Tetapi keduanya mempunyai permukaan koloni cembung. Isolat A berwarna krem dan inti atau bagian tengah koloninya berwarna putih, sedangkan isolat 5 berbentuk oval dan berwarna putih kecoklatan.

Tabel 4 menyajikan kelompok bakteri aerob dan anaerob yang tumbuh pada media TSA dengan suplementasi minyak zaitun $2 \%$ Bakteri yang tumbuh pada media ini diharapkan adalah kelompok bakteri yang dapat memanfaatkan lemak sebagai substrat dan dapat

Tabel 2. Performansi kandidat probiotik bersifat aerob dan anaerob pada media TSA yang disuplementasi skim milk $2 \%$

Table2. The performance of aerobe and anaerobe probiotic bacteria on TSA medium supplemented with $2 \%$ of skim milk

\begin{tabular}{ccccc}
\hline $\begin{array}{c}\text { Inkubasi media } \\
\text { Incubation media }\end{array}$ & $\begin{array}{c}\text { Kode bakteri } \\
\text { Bacteri code }\end{array}$ & $\begin{array}{c}\text { Pengenceran } \\
\text { Dilution }\end{array}$ & $\begin{array}{c}\text { Tipe koloni } \\
\text { Colony type }\end{array}$ & $\begin{array}{c}\text { Warna koloni } \\
\text { Colony color }\end{array}$ \\
\hline $\begin{array}{l}\text { Aerob } \\
\text { Aerobe }\end{array}$ & LL & $10^{14}$ & $\begin{array}{c}\text { Oval, proteolisis } \\
\text { Oval, proteolytic } \\
\text { Bulat, proteolisis } \\
\text { Round, proteolytic }\end{array}$ & Kuning (Yellow) \\
\hline PP & $10^{14}$ & Putih (White) \\
Anaerob & BL & $10^{8}$ & $\begin{array}{c}\text { Bulat, proteolisis } \\
\text { Round, proteolysis } \\
\text { Oval, proteolisis } \\
\text { Oval, proteolytic }\end{array}$ & Putih (White) \\
& OL & $10^{8}$ & Putih (White) \\
\hline
\end{tabular}


Tabel 3. Performansi kandidat probiotik bersifat aerob dan anaerob pada media TSA suplemen pati $2 \%$

Table 3. The performance of aerobe and anaerobe probiotics bacteria on TSA medium supplemented with $2 \%$ starch

\begin{tabular}{|c|c|c|c|c|}
\hline $\begin{array}{l}\text { Inkubasi media } \\
\text { Incubation media }\end{array}$ & $\begin{array}{l}\text { Kode bakteri } \\
\text { Bacteri code }\end{array}$ & $\begin{array}{l}\text { Pengenceran } \\
\text { Dilution }\end{array}$ & $\begin{array}{l}\text { Tipe koloni } \\
\text { Colony type }\end{array}$ & $\begin{array}{l}\text { Warna koloni } \\
\text { Colony color }\end{array}$ \\
\hline Aerob (Aerobe) & A & $10^{8}$ & $\begin{array}{l}\text { Bulat, amilolisis, inti putih } \\
\text { Round, amylolytic, white } \\
\text { cell nucleus }\end{array}$ & Krem (Beige ) \\
\hline Aerob (Aerobe) & 1 & $10^{8}$ & $\begin{array}{c}\text { Bulat, inti putih } \\
\text { Round, white cell nucleus }\end{array}$ & Coklat (Brown) \\
\hline Aerob (Aerobe) & 5 & $10^{6}$ & $\begin{array}{l}\text { Oval, amilolisis } \\
\text { Oval, amylolytic }\end{array}$ & $\begin{array}{l}\text { Putih kecok- } \\
\text { latan (Brownies } \\
\text { white) }\end{array}$ \\
\hline Anaerob (Anaerobe) & $1 \mathrm{An}$ & $10^{11}$ & $\begin{array}{l}\text { Bulat, kecil } \\
\text { Round, small }\end{array}$ & $\begin{array}{l}\text { Putih susu } \\
\text { Milky white }\end{array}$ \\
\hline Anaerob (Anaerobe) & 2 & $10^{9}$ & $\begin{array}{l}\text { Bulat, tepi bergerigi } \\
\text { Round, serrated verge }\end{array}$ & Krem (Beige ) \\
\hline Anaerob (Anaerobe) & 3 & $10^{9}$ & $\begin{array}{l}\text { Bulat, kecil } \\
\text { Round, small }\end{array}$ & Krem (Beige ) \\
\hline Anaerob (Anaerobe) & 4 & $10^{9}$ & Oval (Oval) & Kuning (Yellow \\
\hline Anaerob (Anaerobe) & $5 \mathrm{An}$ & $10^{9}$ & Bulat (Round) & Kuning (Yellow \\
\hline Anaerob (Anaerobe) & $\mathrm{P}$ & $10^{8}$ & $\begin{array}{l}\text { Bulat, kecil } \\
\text { Round, small }\end{array}$ & Putih (White) \\
\hline Anaerob (Anaerobe) & $\mathrm{O}$ & $10^{8}$ & $\begin{array}{l}\text { Oval, kecil } \\
\text { Oval, small }\end{array}$ & $\begin{array}{l}\text { Putih susu } \\
\text { Milky white }\end{array}$ \\
\hline Anaerob (Anaerobe) & $\mathrm{K}$ & $10^{8}$ & $\begin{array}{l}\text { Bulat, kecil } \\
\text { Round, small }\end{array}$ & Kuning (Yellow \\
\hline Anaerob (Anaerobe) & $\mathrm{KB}$ & $10^{8}$ & $\begin{array}{l}\text { Bulat, besar } \\
\text { Round, big }\end{array}$ & Kuning (Yellow \\
\hline
\end{tabular}

menghidrolisis lemak. Total kelompok kandidat bakteri probiotik yang diperoleh ada 7 buah isolat.

Uji hidrolisis lemak yang dilakukan terhadap isolat- isolat pada Tabel 4 menunjukkan bahwa dari kelompok bakteri aerob didapatkan tiga isolat bakteri positif dapat menghidrolisis lemak yaitu isolat $K, P$, dan PG. Sedangkan dari kelompok bakteri anaerob tidak ada satupun yang dapat menghidrolisis lemak. Ketiga isolat terpilih sama dalam bentuknya yaitu bulat dan kecil tetapi berbeda warna koloninya. Isolat $\mathrm{K}$ mempunyai tepi koloni bergerigi.

Setelah isolasi dan uji hidrolisis, selanjutnya dilakukan identifikasi dengan uji biokimiawi dengan hasil disajikan pada Tabel 5.
Dari hasil identifikasi kandidat bakteri disajikan pada Tabel 5 diperoleh hasil bahwa bakteri genus Staphylococcus ternyata dijumpai pada ketiga kelompok: bakteri proteolitik, amilolitik, maupun lipolitik. Pada kelompok bakteri proteolitik, hanya genus Micrococcus yang tumbuh pada media TSA ditambah skim milk $2 \%$ Pada kelompok bakteri amilolitik selain Staphylococcus, didapatkan juga bakteri Corynebacterium, Bacillus, Lactobacillus, dan Micrococcus. Sedangkan untuk bakteri lipolitik, didapatkan bakteri Staphylococcus, Corynebacterium, Micrococcus, Aerococcus, dan Streptococcus.

Genus Staphylococci terdiri atas Staphylococcus, Micrococcus, dan Aerococcus. 
Tabel 4. Performansi kandidat probiotik bersifat aerob dan anaerob pada media TSA suplemen minyak zaitun $2 \%$

Table4. The perfor mance of aerob and anaer obe of probiotic bacteria on TSA medium supplemented with $2 \%$ olive oil

\begin{tabular}{|c|c|c|c|c|}
\hline $\begin{array}{l}\text { Inkubasi media } \\
\text { Incubation media }\end{array}$ & $\begin{array}{l}\text { Kode bakteri } \\
\text { Bacteri code }\end{array}$ & $\begin{array}{l}\text { Pengenceran } \\
\text { Dilution }\end{array}$ & $\begin{array}{l}\text { Tipe koloni } \\
\text { Colony type }\end{array}$ & $\begin{array}{l}\text { Warna koloni } \\
\text { Colony color }\end{array}$ \\
\hline Aerob (Aerobe) & $\mathrm{K}$ & $10^{8}$ & $\begin{array}{c}\text { Bulat, kecil, tepi } \\
\text { bergerigi, lipolisis } \\
\text { Round, small, serrat- } \\
\text { ed verge, lipolytic }\end{array}$ & Kuning (Yellow) \\
\hline Aerob (Aerobe) & $\mathrm{P}$ & $10^{7}$ & $\begin{array}{l}\text { Bulat, kecil, lipolisis } \\
\text { Round, small, } \\
\text { lipolytic }\end{array}$ & Putih (White) \\
\hline Aerob (Aerobe) & PG & $10^{7}$ & $\begin{array}{c}\text { Bulat, kecil, lipolisis } \\
\text { Round, small, } \\
\text { lipolytic }\end{array}$ & $\begin{array}{l}\text { Oranye } \\
\text { Orange }\end{array}$ \\
\hline Anaerob (Anaerobe) & $A$ & $10^{8}$ & Oval (Oval) & $\begin{array}{l}\text { Putih susu } \\
\text { Milky white }\end{array}$ \\
\hline Anaerob (Anaerobe) & $\mathrm{B}$ & $10^{8}$ & Bulat (Round) & Putih (White) \\
\hline Anaerob (Anaerobe) & C & $10^{8}$ & $\begin{array}{l}\text { Bulat, kecil } \\
\text { Round, small }\end{array}$ & Kuning (Yellow) \\
\hline Anaerob (Anaerobe) & $\mathrm{D}$ & $10^{8}$ & $\begin{array}{l}\text { Oval, kecil } \\
\text { Oval, small }\end{array}$ & Kuning (Yellow) \\
\hline
\end{tabular}

Karakter umum dari kelompok ini adalah bentuk sel kokus, gram positif, aerobik, katalase positif, tidak menghasilkan indol dan $\mathrm{H}_{2} \mathrm{~S}$. Staphylococcus lebih terkenal sebagai kelompok patogen dibanding dua kelompok lainnya. Ketiga anggota Staphylococci itu ditemukan sebagai kandidat bakteri probiotik. Bakteri kelompok Staphylococci hidup bebas dalam lingkungan dan hidup berkelompok. Menurut Katoch (2011), evaluasi yang digunakan untuk menguji keamanan probiotik yang diperuntukkan manusia menyatakan bahwa strain bakteri dikatagorikan sebagai Generally Recognised as Safe (GRAS) jika dikarakterisasi melalui uji resistensi antibiotika, uji ada tidaknya efek samping jika dimakan, jika strain itu dikenal sebagai strain produksi toksin atau mempunyai potensi hemolitik seperti Staphylococcus maka perlu diuji terlebih dahulu untuk meyakinkan keamanannya. Berdasarkan pernyataan tersebut, maka Staphylococcus dipilih sebagai urutan terakhir untuk kandidat probiotik karena dikenal sebagai strain yang dapat memproduksi toksin dan mempunyai aktivitas hemolisis sehingga harus diuji secara lebih detail.
Genus Bacillus termasuk batang besar, gram positif, aerob yang membentuk rantai. Kebanyakan anggota genus ini adalah organisme saprofit yang lazim terdapat dalam tanah, air, udara, dan tumbuh- tumbuhan. Beberapa dari genus Bacillus menghasilkan enzim hidrofilik ekstraseluler yang dapat memecah polisakarida, asam- asam nukleat, dan lemak, serta menggunakannya sebagai sumber karbon dan energi. Kemampuannya dalam menguraikan bahan- bahan organik menyebabkan genus Bacillus berperan penting dalam proses dekomposisi bahan organik. Beberapa jenis dari genus Bacillus dapat menghasilkan senyawa antibiotik seperti bacitracin, polymixin, tyrocidin, gramicidin, dan circulin (Buchanan, 1974 dalam Abadi, 2009).

Fuller (1992) menyatakan bahwa genus Bacillus (1) mampu tumbuh pada suhu lebih dari $50^{\circ} \mathrm{C}$, mampu tumbuh pada konsentrasi garam tinggi ( $>10 \%$ dan mampu menghasilkan spora. Melihat sifat yang dimiliki Bacillus maka biakan mikroba dapat digunakan di luar maupun di dalam saluran pencernaan dengan cara menumbuhkan populasi mikrobial dalam jumlah 
Tabel 5. Hasil uji identifikasi biokimiawi kandidat probiotik dari saluran cerna ikan lele

Table5. Biochemical and physiological identification of probiotic candidate isolated from digestive tract of Clarias sp.

\begin{tabular}{|c|c|c|c|c|c|c|c|c|c|c|c|c|}
\hline KB & Gram & $\begin{array}{l}\text { Bentuk } \\
\text { Shape }\end{array}$ & $\begin{array}{c}\text { Uji } \\
\text { O/F } \\
\text { O/F } \\
\text { test }\end{array}$ & $\mathbf{M}$ & $\mathbf{I}$ & $\mathbf{s}$ & G & $\mathbf{K}$ & C & $\mathbf{P}$ & $\mathbf{L}$ & $\begin{array}{l}\text { Diagnosa } \\
\text { Diagnosa }\end{array}$ \\
\hline \multicolumn{13}{|c|}{ Susu skim (Skim milk) 2\% } \\
\hline PP & + & Kokus (Coccus ) & + & + & - & - & - & + & - & & & Micrococcus \\
\hline $\mathrm{LL}$ & + & Kokus (Coccus ) & + & + & - & - & + & + & + & & & Micrococcus \\
\hline $\mathrm{BL}$ & + & Kokus (Coccus ) & + & + & - & - & - & + & - & & & Micrococcus \\
\hline OL & + & Kokus (Coccus ) & + & + & - & - & - & + & + & & & Micrococcus \\
\hline \multicolumn{13}{|c|}{ Pati (Starch ) 2\% } \\
\hline 5 & + & Kokus (Coccus ) & + & + & - & - & - & + & & + & & Staphylococcus \\
\hline 1 & + & Batang (Rod) & + & + & + & - & - & + & & - & & Corynebacterium \\
\hline$A$ & + & Batang (Rod) & - & - & - & - & - & - & & + & & Bacillus \\
\hline$P$ & + & Batang (Rod) & - & - & - & - & - & + & & - & & Corynebacterium \\
\hline $\mathrm{O}$ & + & Kokus (Coccus ) & - & - & - & - & - & + & & - & & Micrococcus \\
\hline $\mathrm{K}$ & + & Batang (Rod) & - & - & - & - & + & + & & + & & Bacillus \\
\hline KB & + & Batang (Rod) & + & + & - & - & - & - & & + & & Lactobacillus \\
\hline 1 & + & Kokus (Coccus ) & + & + & - & - & + & + & & - & & Micrococcus \\
\hline 2 & + & Kokus (Coccus ) & + & + & - & - & + & + & & + & & Micrococcus \\
\hline 3 & + & Kokus (Coccus ) & + & + & - & - & + & + & & + & & Micrococcus \\
\hline 4 & + & Kokus (Coccus ) & + & + & - & - & + & + & & + & & Micrococcus \\
\hline 5 & + & Batang (Rod) & - & - & - & - & - & + & & - & & Corynebacterium \\
\hline \multicolumn{13}{|c|}{ Minyak zaitun (Olive oil) $2 \%$} \\
\hline PG & + & Kokus (Coccus) & + & + & - & - & + & + & & & + & Staphylococcus \\
\hline $\mathrm{P}$ & + & Kokus (Coccus) & + & + & + & - & + & + & & & - & Micrococcus \\
\hline K & + & Kokus (Coccus) & - & + & - & - & - & + & & & - & Micrococcus \\
\hline$A$ & + & Kokus (Coccus) & + & + & - & - & - & + & & & + & Aerococcus \\
\hline B & + & Kokus (Coccus) & + & + & + & + & - & - & & & + & Streptococcus \\
\hline C & + & Batang (Rod) & + & + & + & + & - & + & & & + & Corynebacterium \\
\hline $\mathrm{D}$ & + & Batang (Rod) & - & - & - & - & - & + & & & + & Corynebacterium \\
\hline
\end{tabular}

Keterangan (Note):

$\mathrm{KB}=$ Kode bakteri (Bacteri code)

$M=$ Uji motilitas (Motility test)

$\mathrm{I}=\mathrm{Uji}$ indol (Indole test)

$\mathrm{S}=$ Uji sulfida (Sulfide test)

$\mathrm{G}=$ Uji gelatin (Gelatine test)

$\mathrm{K}=$ Uji katalase (Catalase test)

$\mathrm{C}=$ Uji kasein (Casein test)

$\mathrm{P}=$ Uji pati (Starch test)

$\mathrm{L}=$ Uji lemak (Lipid test) 
yang tepat sehingga dapat sebagai al ternatif karena dengan meningkatkan populasinya maka dapat dipergunakan untuk menekan pertumbuhan bakteri patogen.

Sedangkan genus Streptococcus adalah bakteri gram positif berbentuk bulat yang secara khas membentuk pasangan atau rantai selama masa pertumbuhannya. Bakteri ini tersebar luas di alam. Genus Streptococcus bervariasi ada yang menguntungkan dan merugikan, sehingga jika nanti dipertimbangkan sebagai kandidat probiotik maka harus diuji lebih lanjut untuk mengetahui strain ini patogen atau tidak.

Genus Corynebacterium banyak dikaitkan dan dikenal sebagai patogen pada manusia. Sehingga untuk uji kandidat bakteri probiotik lebih Ianjut (Katoch, 2011), diutamakan Staphylococcus dan Corynebacterium dapat diuji secara in vivo untuk mengetahui bakteribakteri tersebut patogen atau tidak.

Nopitawati (2010) mengisolasi bakteri proteolitik, lipolitik, dan amilolitik dari saluran pencernaan udang vaname dan mendapatkan empat spesies bakteri kandidat probiotik. Uji biologis yang meliputi pertumbuhan dan kecernaan nutrien pada udang vaname yang mendapat perlakuan keempat spesies probiotik tersebut mendapatkan hasil bahwa pertumbuhan tertinggi terdapat pada udang yang mendapat tambahan probiotik proteolitik, sedangkan kecernaan total dan protein yang tertinggi terdapat pada udang yang mendapat tambahan probiotik yang memiliki aktivitas proteolitik, lipolitik, dan amilolitik sekaligus. Sedangkan Kurniasih et al. (2013b) mengisolasi bakteri proteolitik dari saluran pencernaan ikan lele dan air media pemeliharaan lele dan mendapatkan dua spesies bakteri proteolitik sebagai kandidat probiotik dan juga penghasil enzim protease. Hasil uji biologis dilaporkan oleh Kurniasih et al. (2013a) bahwa kecernaan protein dan total pakan mengalami peningkatan dari 74,8\%menjadi 90,2\%dan dari 48,4\%menjadi 75,9\% Laju pertumbuhan juga mengalami perbedaan signifikan dari pakan kontrolnya, dari $2,33 \%$ hari menjadi $2,75 \%$ hari, dan efisiensi pakan dari 75,9\% menjadi $82,7 \%$ Dari hasil penelitian Nopitawati (2010), Kurniasih et al. (2013a; 2013b), memberikan kejelasan peranan bakteri proteolitik, amilolitik, dan lipolitik di dalam meningkatkan kecernaan, sehingga diharapkan penelitian lebih lanjut dari ketujuh isolat hasil penelitian ini yang terdiri atas dua bakteri proteolitik (BL dan OL), dua bakteri amilotik (A dan 5) dan tiga bakteri lipolitik (K, P, dan PG) dapat dilakukan untuk mengetahui potensi masing-masing bakteri lebih detail.

\section{Uji Daya Hambat Kandidat Probiotik Terhadap Aeromonas hydrophila}

Uji daya hambat terhadap bakteri patogen atau uji antagonisme adalah untuk melihat kemampuan kandidat probiotik di dalam menghambat atau membunuh bakteri patogen. Bakteri patogen yang digunakan adalah A. hydrophila. Menurut Burton \& Lanza (1987), A. hydrophila merupakan bakteri yang umum ditemukan di perairan, dengan tingkat kepadatan yang berkorelasi dengan kandungan nutrien di perairan tersebut. Bahan organik yang berasal dari sisa pakan dapat memicu peningkatan pertumbuhan A. hydrophila sehingga berpotensi menyebabkan penyakit terutama ikan dalam kondisi stres. Uji potensi menggunakan kertas cakram dengan kepadatan $A$. hydrophila sebanyak $10^{8} \mathrm{CFU} / \mathrm{mL}$ tidak dapat menunjukkan adanya zona bening di sekitar kertas cakram yang disebut sebagai zona hambat. Demikian juga ketika uji in vitro dilakukan dengan menurunkan kepadatan A. hydrophila hingga $10^{4} \mathrm{CFU} / \mathrm{mL}$, dan juga menaikkan kepadatan bakteri probiotik, ternyata zona hambat tetap tidak terbentuk . Uji in vitro ini bertujuan untuk mendapatkan kandidat bakteri probiotik dengan kemampuan mengendalikan pertumbuhan $A$. hydrophila yang paling baik. Ternyata semua kandidat bakteri probiotik yang diuji secara in vitro tidak berpengaruh terhadap populasi A. Hydrophila, walaupun $A$. hydrophila pada konsentrasi terendah pun setelah diinkubasi dan ditumbuhkan kembali pada cawan petri maka $A$. hydrophila tumbuh mendominasi. Dapat dikatakan bahwa keseluruhan kandidat probiotik yang diuji pada tahap ini ternyata tidak memiliki kemampuan menghambat pertumbuhan patogen $\mathrm{A}$. hydrophila.

\section{Pengawetan dan Penyimpanan Isolat Kandidat Bakteri Probiotik}

Ada beberapa pendapat, isolat probiotik dapat disimpan dalam media gliserol $15 \%$ sampai $20 \%$ tetapi juga ada pendapat lain bahwa penyimpanan dapat memanfaatkan media cair di mana bakteri tersebut biasa hidup dan disuplementasi dengan gliserol. Dari hasil uji maka diperoleh hasil seperti yang disajikan pada Tabel 6. 
Tabel 6. Hasil uji daya simpan isolat kandidat bakteri probiotik pada media gliserol Table 6. Growth and survival of probiotic bacterias cultured in gliserol

\begin{tabular}{|c|c|c|c|}
\hline \multirow{2}{*}{$\begin{array}{l}\text { Jenis isolat kandidat } \\
\text { bakteri probiotik } \\
\text { Type of probiotic } \\
\text { bacteria candidates }\end{array}$} & \multirow{2}{*}{$\begin{array}{r}\text { Inokulan } \\
\text { Inoculant } \\
\text { (cfu/ mL) }\end{array}$} & \multicolumn{2}{|c|}{$\begin{array}{l}\text { Jenis media penyimpan } \\
\text { Storage medium type }\end{array}$} \\
\hline & & TSB:Gliserol (1:1) & Gliserol \\
\hline $\mathrm{BL}$ & $10^{14}$ & $\begin{array}{l}\text { Tumbuh subur } \\
\text { Good growth }\end{array}$ & $\begin{array}{l}\text { Tidak subur } \\
\text { Poor growth }\end{array}$ \\
\hline PP & $10^{14}$ & $\begin{array}{l}\text { Tumbuh subur } \\
\text { Good growth }\end{array}$ & $\begin{array}{l}\text { Tidak subur } \\
\text { Poor growth }\end{array}$ \\
\hline A & $3 \times 10^{9}$ & $\begin{array}{l}\text { Tumbuh subur } \\
\text { Good growth }\end{array}$ & $\begin{array}{l}\text { Tidak subur } \\
\text { Poor growth }\end{array}$ \\
\hline 5 & $5 \times 10^{6}$ & $\begin{array}{l}\text { Tumbuh subur } \\
\text { Good growth }\end{array}$ & $\begin{array}{l}\text { Tidak subur } \\
\text { Poor growth }\end{array}$ \\
\hline K & $4 \times 10^{8}$ & $\begin{array}{l}\text { Tumbuh subur } \\
\text { Good growth }\end{array}$ & $\begin{array}{l}\text { Tidak subur } \\
\text { Poor growth }\end{array}$ \\
\hline$P$ & $2 \times 10^{11}$ & $\begin{array}{l}\text { Tumbuh subur } \\
\text { Good growth }\end{array}$ & $\begin{array}{l}\text { Tidak subur } \\
\text { Poor growth }\end{array}$ \\
\hline PG & $2 \times 10^{12}$ & $\begin{array}{l}\text { Tumbuh subur } \\
\text { Good growth }\end{array}$ & $\begin{array}{l}\text { Tidak subur } \\
\text { Poor growth }\end{array}$ \\
\hline
\end{tabular}

Dari hasil Tabel 6 maka penyimpanan dengan menggunakan TSB dan gliserol 1:1 memberikan hasil terbaik dengan pertumbuhan yang subur dari isolat tersebut setelah ditumbuhkan kembali pada TSA. Perbandingan antara TSB dan gliserol 1:1, sesuai dengan Badjoeri (2010) bahwa preservasi mikroba untuk jangka waktu pendek antara 1 sampai 3 bulan menggunakan TSB dan gliserol dengan perbandingan $1: 1$.

\section{KESIMPULAN DAN SARAN}

\section{Kesimpulan}

1. Telah dapat diisolasi tujuh isolat kandidat bakteri probiotik dari saluran pencernaan ikan lele yaitu dua isolat proteolitik, dua isolat amilolitik, dan tiga isolat lipolitik.

2. Kandidat bakteri probiotik tersebut terdiri atas genus Micrococcus, Bacillus, Staphylococcus, dan Corynebacterium.

\section{Saran}

Perlu dilakukan penelitian Ianjutan untuk mengetahui potensi kandidat bakteri probiotik secara in vivo yang sebelumnya harus dilakukan uji patogenitas terlebih dahulu. Ada suatu aturan seleksi bakteri probiotik yaitu
GRAS (generally recognized as safe), di mana bakteri probiotik tidak boleh diambil dari suatu genus yang salah satu anggotanya bersifat patogen, seperti misalnya Streptococcus, Staphylococcus, Pseudomonas, dan lain- Iain.

\section{DAFTARACUAN}

Abadi, A.F. 2009. Pengaruh pemberian suplemen pakan yang mengandung Bacillus sp. dalam pakan buatan terhadap laju pertumbuhan benih ikan nila. Fakultas Perikanan dan Ilmu Kelautan. Universitas Padjadjaran, Bandung, $41 \mathrm{hlm}$.

Aslamyah, S. 2006. Pengunaan mikroflora saluran pencernaan sebagai probiotik untuk meningkatkan pertumbuhan dan kelangsungan hidup ikan bandeng. Disertasi. Sekolah Pasca Sarjana. Institut Pertanian Bogor, Bogor, $256 \mathrm{hlm}$.

Badjoeri, M. 2010. Preservasi mikroba untuk pelestarian dan stabilitas plasma nutfah. Warta Limnologi No. 45/th XXII. Pusat Limnologi LIPI, hlm. 14- 18.

Burton, G.A. Jr. \& Lanza, G.R. 1987. Aeromonas hydrophylla densities in thermally altered reservoir water and sediments. Water, air, and soil pollution, 34: 199- 206.

Cai, Y., Benno, T., Naskase, Y., \& Tae- Kwang, O. 
1998. Specific probiotic characterization of Weisella hellenica DS- 12 isolated from flounder intestine. Genet. Microbiol., 44: 311- 316.

Fuller, R. 1992. History and development of probiotics. In Fuller, R. (Ed.). Probiotics: the scientific Basis. Chapman and Hall, New York, p. 1-8.

Hoshino, T., Ishizaki, K., \& Sakamoto, T. 1997. Isolation of a Pseudomonas species from fish intestine that produces an active protease at low temperature. Lett. Appl. Microbiol., 25(1): 70- 72.

Hungate, R. 1966. The Rumen and its Microbes. London and New York, Academic Press. $533 \mathrm{pp}$.

Jankauskiene, R. 2000. The dependence of the species composition of lactoflora in the intestinal tract of carps upon their age. Acta Zoologica Lituanica, 10(3): 78- 83.

Katoch, V.M. 2011. Guidelines for evaluation of probiotics in food. Indian Council of Mediac Research ICMR- DBT, 25 pp.

Kurniasih, T., Utomo, N.B.P., Azwar, Z.I., Mulyasari, \& Melati, I. 2013a. Perbaikan kualitas pakan dan kinerja pertumbuhan ikan nila dengan penambahan enzim pro- tease bakteri pada pakan formulasi. J. Ris. Akuakultur, 8(1): 87- 96.

Kurniasih, T., Widanarni, Mulyasari, Melati, I., \& Azwar, Z.I. 2013b. Isolasi, seleksi dan identifikasi bakteri dari saluran pencernaan ikan lele sebagai kandidat probiotik. J. Ris. Akuakultur, 8(2): 277- 286.

Moriarty, D.J.W. 1999. Disease control in shrimp aquaculture with probiotic bacteria. In Bell, C.R., Brylinsky, M., \& Johnson- Green, P. (Eds.) Microbial System: New Frontiers. Proceedings of the $8^{\text {th }}$ International Symposium on Microbial Ecology. Atlantic Canada Society for Microbial Ecology, Halifax, Canada, 7 pp.

Nakayama, A., Yano, Y., \&Yoshida, K. 1994. New method for isolating Barophiles from intestinal contents of deep sea fishes retrieved from the abyssal zone. Appl. and Environm. Microbiol., 60(11): 4,210-4,212.

Nopitawati, T. 2010. Seleksi bakteri probiotik dari saluran pencernaan untuk meningkatkan kinerja pertumbuhan udang vaname Litopenaeus vannamei. Tesis. Sekolah Pascasarjana Insitut Pertanian Bogor, Bogor, $63 \mathrm{hlm}$. 